\title{
UTANG LUAR NEGERI INDONESIA DALAM PERSPEKTIF EKONOMI SYARIAH \\ Choirunnisak
}

Perbankan Syariah STEBIS IGM Palembang

Emai: Choirunnisak-umar@stebisigm.ac.id

\begin{abstract}
ABSTRAK
"Penlitian ini membahas tentang bagaimana utang luarnegri Indonesia dan konsep utang luarnegri dalam pesfektif ekonomi syariah, Hasil penelitian ini utang luarnegi Indosia semakin bertambah dan menghawatirkan, dan utang luarnegri di bolehkan selama tidak mengandung riba, mampu membayar dan merupakan kebutuhan yang mendesak."
\end{abstract}

Kata Kunci: Utang Luar Negeri, Ekonomi Islam.

\section{DASAR PEMIKIRAN}

Mengutif dari Dr Jerry Massie MA, DMin, Ph.D (Peneliti Kebijakan Publik Indonesia Public Institute) Ketua Dewan Pakar LAPD. Baranewsaceh.co 31 Oktober 2018. Pukul 16.15. wib. Debt dalam bahasa inggris-nya yang berarti "hutang" dalam bahasa latin "Debitum. Sejauh ini, pemerintah pusat mengalami kenaikan utang sebanyak 48\% (atau hampir dua kali lipat dari pemerintahan sebelumnya) semenjak Presiden Joko "Jokowi" Widodo memulai pemerintahannya pada 2014. Dari data Kementerian Keuangan, jumlah utang pemerintah di akhir 2014 adalah Rp 2.604,93 triliun, dan naik hingga posisi di akhir April 2017 menjadi Rp 3.667,41 triliun. Dibanding dengan utang negara pada akhir pemerintahan Presiden Susilo Bambang Yudhoyono (SBY) pada 2014 berkisar di angka US\$122 miliar. Selama 4 tahun masa pemerintahan Presiden Jokowi, utang tersebut bertambah 48\% hingga mencapai US\$181 miliar. Penambahan utang yang terjadi cukup besar jika dibandingkan dengan masa pemerintahan SBY; antara 2009 dan 2013 utang negara naik di kisaran 26\%. Pada data yang dikeluarkan Bank Indonesia (BI) Februari lalu, Utang Luar Negeri (ULN) Indonesia 2017 silam mencapai US\$352,2 miliar atau sekitar Rp4.849 triliun (kurs Rp13.769). Jumlah itu naik 10,1\% dibandingkan tahun sebelumnya. (www. baranewsaceh.co 31 oktober 2018. pukul 16.15. wib.)

Bank Indonesia (BI) merilis jumlah utang per periode triwulan II 2018. Tercatat, utang luar negeri Indonesia (ULN) pada periode tersebut mencapai 355,7 miliar dolar AS atau setara Rp5.193,2 triliun.Berdasarkan keterangan resmi Bank Indonesia, utang tersebut terdiri dari utang pemerintah dan bank sentral sebesar 179,7 miliar dolar AS 
atau Rp2.623,6 triliun, serta utang swasta sebesar 176 miliar dolar AS atau Rp2.569,6 triliun.Indonesia terus berhutang sejak menjadi anggota IMF sejak 1967. Adapun Indonesia pernah berutang US\$ 9,1 miliar ke IMF terkait krisis 1998. Namun, utang tersebut sudah lunas di 2006. Kementerian Keuangan mencatat utang pemerintah hingga September 2018 sebesar Rp 4.416,3 triliun, atau 30,47 persen terhadap Produk Domestik Bruto (PDB). Adapun perkiraan PDB sebesar Rp 14.395,07 triliun. "Rasio tersebut masih jauh di bawah batas bawah batas 60 persen terhadap PDB sebagaimana ketentuan Undang-undang Keuangan Negara Nomor 17 Tahun 2003," kutip keterangan tertulis Kementerian Keuangan, Rabu, 17 Oktober 2018. Jumlah utang hingga September itu lebih tinggi dari bulan sebelumnya yang sebesar Rp 4.363,2 atau sebanding dengan 30,31 persen terhadap PDB. Total utang pemerintah pusat pada September, terbagi atas pinjaman Rp 823,1 triliun dan surat berharga negara (SBN) Rp 3.593,2 triliun. Dalam pinjaman terdapat pinjaman luar negeri medenominasi rupiah sebesar Rp 2.537,1 dan denominasi valas sebesar Rp 1.056,1 (Ibid)

Berangkat dari permasalahan diatas, penulis tertarik membahas bagaimana konsep Ekonomi Islam terhadap Utang Luar Negri. Karena Islam merupakan agama yang bukan hanya mengatur urusan agama atau ibadah saja tetapi semua kompones hidup telah diatur sedemikian rupa. Termasuk utang luar negri.

Penelitian ini merupakan jenis penelitian pustaka (library research) yang menitikberatkan pada pengelolaan data secara kualitatif dengan metode analisis data menggunakan metode deskriptif-analisis. Penelitian ini bertujuan untuk menggambarkan atau atau membeberkan apa yang terjadi sekarang (Arikunto, 2002:9), dan mengeksplorasi fenomena-fenomena yang tidak dapat dikuantifikasikan (Satori dan Komariah, 2009: 23). Selain itu, deskriptif penting karena merupakan metode analisis data yang berfungsi untuk menjelaskan suatu pemikiran (fakta) sehingga dapat diterima secara rasional (surabaya, 2007: 18)

\section{TINJAUAN PUSTAKA}

Skripsi 2017 yang ditulis oleh Dwi Kurniasari Universitas Lampug yang berjudul Pengaruh utang luar negri, penanaman modal asing, penanaman modal dalam negri dan tenaga kerja terhadap pertumbuhan ekonomian Indonesia. Pertumbuhan ekonomi merupakan salah satu asumsi dasar ekonomi makro dilihat dalam Anggaran 
Pendapatan dan Belanja Negara (APBN) untuk mencapai tujuan pembangunan. Adanya ketidak seimbangan yang terjadi pada sisi penerimaan dan pengeluaran menimbulkan kondisi defisit Anggara. Hal ini beresiko kekurangan dalam memenuhi kebutuhan pembangunan ekonomi untuk memacu pertumbuhan ekonomi.Penelitian ini bertujuan untuk mengetahui bagaimanapengaruhutang luar negeri, penanaman modal asing, penanaman modal dalam negeri dan tenaga kerja terhadap pertumbuhan ekonomi di Indonesia.Secara empiris, data times series yang di gunakan pada tahun 1985-2014 dengan menggunakan model analisis ECM (Error Corection Model) untuk mengetahui pengaruh dalam jangka pendek. Hasil estimasi menggunakan model ECM semua variabel bebas secara bersama -sama signifikan terhadappertumbuhan ekonomi .Secara parsial metode ECM menunjukan bahwa dalam jangka pendek variabel penanaman modal asing, penanaman modal dalam negeri dan tenaga kerja berpengaruh signifikan terhadappertumbuhan ekonomi, sedangkan utang luar negeri, tidak berpengaruh signifikan terhadap pertumbuhan ekonomi.( skripsi : 2017)

Niati Tafonao 20016 Universitas diponegoro analisis faktor-faktor yang mempengaruhi utang luar negri. Penelitian ini bertujuan untuk Menganalisis Faktor-Faktor Yang Mempengaruhi Utang Luar Negeri Indonesia. Yang digunakan dalam penelitian ini meliputi data tahunan sejak (1996 -2014). Alat analisis yang digunakan dalam penelitian ini adalah regresi OLS (Ordinary Least Square). Hasil analisis Ordinary Least Square menunjukkan bahwa suku bunga dalam negeri, pertumbuhan ekonomi tidak memiliki pengaruh signifikan terhadap total utang pemerintah, nilai tukar berpengaruh positif signifikan terhadap total utang, sedangkan keseimbangan primer (Primery Balance) berpengaruh negatif yang signifikan terhadap total utang pemerintah. Hasil analisis menunjukan bahwa suku bunga Indonesia merupakan variabel yang paling besar kontribusinya dalam menjelaskan faktor-faktor yang mempengaruhi utang luar negeri.(Skripsi: 2016)

Skripsi Daniel Eka Bonokeling UNY 2016 Pengaruh Utang Luar Negri, Tenaga Kerja, dan Ekspor, terhadap produk domestik bruto di Indonesia tahun 19862015. Penelitian ini bertujuan untuk mengetahui pengaruh utang luar negeri, tenaga kerja, dan ekspor terhada $\mathrm{p}$ produk domestik bruto Indonesia. Pene litian ini menggunakan pendekantan kuantitatif. Data yang digunakan berupa data sekunder Indonesia dari tahun 1986-2015. Teknik analisis data dalam penelitian ini menggunakan 
analisis data time series dengan model ECM (Error Correction Model). Hasil penelitian menunjukkan bahwa: (1) Variabel utang luar negeri berpengaruh positif terhadap PDB sebesar 0,19\% dalam jangka panjang dan sebesar 0,08\% dalam jangka pendek. (2) Variabel tenaga kerja berpengaruh posit if terhada p PDB sebesar 6,05\% dalam jangka panjang dan sebe sar 2,73\% da lam jangka pendek. (3) Variabe 1 ekspor berpengaruh positif terhadap PDB sebesar 0,27\% dalam jangka panjang dansebesar 0,11\% da lamjangka pe ndek. (4) Variabe 1 ECT sebe sar -1.006077 artinya menunjukkan proporsi biaya ketidak seimbangan dan pergerakan PDB pada periode sebelumnya yang disesuaikan dengan periode sekarang adalah sebesar 100,6\%. (5)Variabe lutang luar negeri, tenaga kerja,dan ekspor secara simultan berpengaruh positif terhadap PDB baik dalam jangka panjang maupun jangka pendek. (Skripsi : 2016)

\section{PEMAHAMAN}

\section{A. Daftar Negara Pemberi Utang pada Indoenesia}

Berikut adalah pemberi pinjaman bilateral dan multilateral terbesar buat Indonesia, seperti dikutip dari data Ditjen Pengelolaan Pembiayaan dan Risiko Kementerian Keuangan, Selasa (27/6/2017). (Ditjen Pengelolaan Pembiayaan dan Risiko Kementerian Keuangan)

\section{Islamic Development Bank (IDB)}

Per Mei 2017, utang pemerintah Indonesia ke IDB mencapai Rp 9,95 triliun, naik tipis dari bulan sebelumnya Rp 9,94 triliun. Persentasenya adalah 1,3\% dari total utang luar negeri Indonesia.

\section{Jerman}

Hingga Mei 2017, utang pemerintah Indonesia ke Jerman mencapai Rp 24,3 triliun, turun tipis dari bulan sebelumnya Rp 24,88 triliun. Persentasenya adalah 3,3\% dari total utang luar negeri pemerintah pusat.

\section{Prancis}

Sampai Mei 2017, utang Indonesia ke Prancis mencapai Rp 24,3 triliun. Naik tipis dari bulan sebelumnya Rp 24,19 triliun. Jumlah tersebut adalah 3,3\% dari total utang luar negeri pemerintah pusat. 


\section{Bank Pembangunan Asia (ADB)}

Utang dari ADB hingga Mei 2017 adalah Rp 119,51 triliun, turun dari bulan sebelumnya Rp 120,91 triliun. Jumlah ini adalah 16,5\% dari total utang luar negeri pemerintah pusat.

\section{Jepang}

Negeri Matahari Terbit ada di posisi kedua pemberi utang terbesar ke pemerintah Indonesia. Per Mei 2017, utang pemerintah Indonesia ke Jepang mencapai Rp 196,98 triliun, turun dari bulan sebelumnya Rp 200,67 trliun. Utang tersebut mencapai $27,2 \%$ dari total pinjaman luar negeri pemerintah.

\section{Bank Dunia}

Bank Dunia kembali pemberi utang terbesar ke pemerintah Indonesia. Jumlahnya hingga Mei 2017 mencapai Rp 234,68 triliun, naik tipis dari bulan sebelumnya Rp 234,49 triliun. Utang Indonesia ke Bank Dunia mencapai 32,4\% dari total utang luar negeri pemerintah. Selain 6 besar ini, Indonesia juga memiliki utang luar negeri ke negara ini:

1) Korea Selatan $\operatorname{Rp} 19,5$ triliun

2) China $\operatorname{Rp} 13,51$ triliun

3) Amerika Serikat (AS) Rp 8,26 triliun

4) Australia Rp 6,95 triliun

5) Spanyol Rp 3,37 triliun

6) Rusia Rp 3,3 triliun

7) Inggris $\mathrm{Rp} 1,92$ triliun

Dilihat dari sisi pertumbuhan, ULN ini meningkat 5,5 persen dari periode yang sama tahun lalu. Namun, pertumbuhan ini bisa dibilang melambat dibandingkan pada triwulan I 2018 sebesar 8,8 persen. Hal ini karena adanya net pelunasan pinjaman dan SBN domestik yang dibeli kembali oleh investor domestik.

Dalam jangka panjang utang luar negeri dapat menimbulkan berbagai macam persoalan ekonomi negara Indonesia, salah satunya dapat menyebabkan nilai tukar rupiah jatuh (Inflasi). Utang luar negeri dapat memberatkan posisi APBN RI, karena utang luar negeri tersebut harus dibayarkan beserta dengan bunganya. 


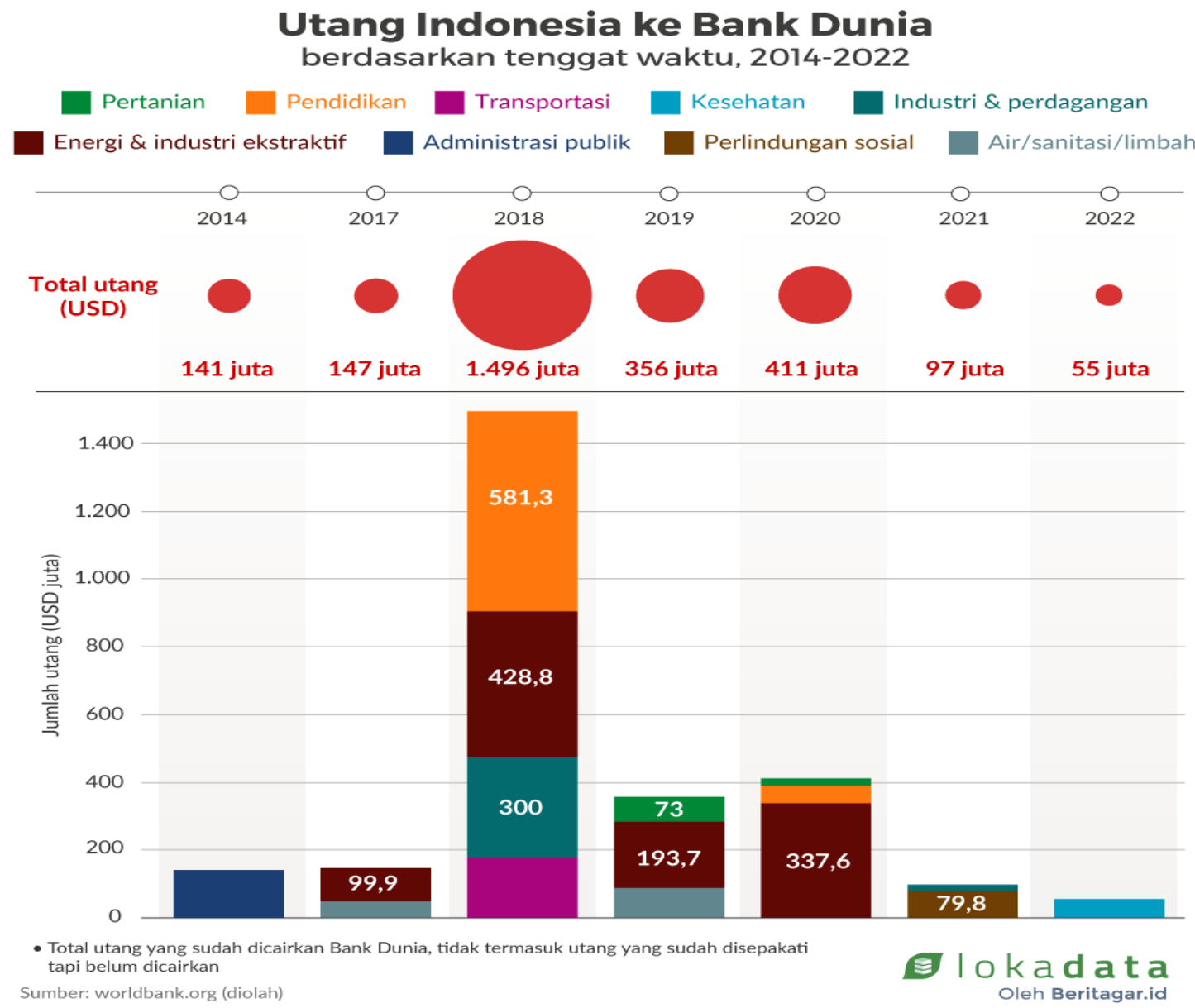

Dalam bahasa Arab, utang (al- Dayn) merupakan sesuatu yang berada dalam tanggung jawab orang lain. Dayn juga disebut juga dengan wasfu alDzimmah(sesuatuyang harus di lunasi atau diselesaikan). Menurut Hanafiyah, dayn termasuk kepada al-Milk.Utang dapat di kategorikan pada al-Mal al-Hukmi::"Sesuatu yang dimiliki oleh pemberi utang, sementara harta itu berada pada ayang berutang”. Sehingga utang begara adalah milik rakyat dan digunakan untuk keperluan rakyat. Selain itu, utang (al-Dayn)secara bahasa juga bermakna memberikan pinjaman. Al- Dayn mensyaratkan jangka waktu tertentu dalam pengembalian utang,hal ini berbeda dengan al- Qardh yang tidak mensyaratkan jangka waktu tertentudalam pengembalian utang. Setiap qardh adalah dayn, tetapi tidak setiap dayn adalah qardh. (Az-Zain, 1995)

Prinsip Utang

1. Utang menjadi alternative terakhir.

2. jika terpaksa berhutang, jangan berutang di luar kemampuan. 
3. jika utang telah dilakukan, harus ada niat untuk membayarnya.

4. Bebas riba

\section{B. Utang Negara}

Diketahui sebuah negara akan dicap sebagai negara miskin dan tukang utang, karena tidak mampu untuk mengatasi perekonomian negara sendiri, (hingga membutuhkan campur tangan dari pihak lain). Selain itu, hutang luar negeri bisa memberikan manfaat sebagai berikut:

1. Membantu dan mempermudah negara untuk melakukan kegiatan ekonomi.

2. Sebagai penurunan biaya bunga APBN

3. Sebagai sumber investasi swasta

4. Sebagai pembiayaan Foreign Direct Investment (FDI) dan kedalaman pasar modal

5. Berguna untuk menunjang pembangunan nasional yang dimiliki oleh suatu negara

\section{Esensi Hutang Negara}

Utang dalam lingkungan keuangan negara dibagai manjadi dua, yaitu utang negara dan utang swasta. Utang pemerintah adalah utang yang dilakukan baik oleh pemerintah pusat maupun daerah(public debt), sedangkan utang swasta adalah pinjaman pihak swasta, baik perorangan maupun perseroan (private debt). (Huda, dkk. 2012 : 245) Setiap tahun RAPBN (Rancangan Anggaraan Pendapatan dan Belanja negara yang diajukan pemerintah kepada dewan perwakilan rakyat (DPR) untuk kemudian disahkan menjadi undang-undang APBN. RAPBN merupakan rencana kebijakan yang akan menjadi kebijakan fiskal. Kebijakan fiskal itu sendiri merupakan suatu kebijakan yang meliputi kegiatan penerimaan dan pengeluaran negara yang digunakan pemerintah untuk menjaga stabilitas ekonomi dan mendorong pertumbuhan ekonomi.

Anggaran belanja negara adalah semua anggaran yang dikeluarkan oleh seluruh tingkat pemerintah melalui dari tingkat pemerintahan pusat sampai kepemerintah daerah. Anggaran belanja ini biasa disebut budget dan biasanya direncanakan setahun sebelumnya. Budget mengambarkan berapa banyak uang yang akan dibelanjakan oleh pemerintah dan untuk keperluan apa saja.

Anggaran belanja atau budget dikelompokkan berdasarkan selisih antara penerima dan pengeluaran, yaitu: 
1. Budget surplus: Yaitu keadaan dimana pemerintah melebihi pengeluarannya. Dalam hal ini pemerintah memperoleh surplus.

2. budget deficit:Yaitu keadaan dimana penerimaan pemerintah lebih kecil daripada pengeluaran. Dalam hal ini pemerintah mengalamideficit.

3. balanced budget:yaitu kondisi dimana penerimaan pemerintah sama besar dengan pengeluaran pemerintah.

Pada umunya saat ini keuangan negara banyak menganut sistem budget deficit. Untuk mengatasi budget deficit biasanya suatu negara meningkatkan penerimaan negara melalui penerimaan pajak dan atau meminjam dana baik dari masyarakat atau pihak lain melalui obligasi atau luar negri. Pinjamandari pihak lain dilakukan jika negara dapat dipastikan mampu mengembalikan pinjaman tersebut. Alternatif lain selain dari pinjaman yaitu mencetak uang.

Dari perspektif Islam, praktik dan proses serta implikasi utang luar negeri tidak sesuai dengan ajaran Islam. Ketidaksesuaian ini bisa dilihat dari berbagai hal Pertama, utang yang didasarkan riba. Bunga mengarah kepada riba yang dilarang oleh Islam, terlepas dari sebarapa rendahnya bunga. Kedua, utang luar negeri menyebabkan jatuhnya martabat bangsa, padahal Islam mengajarkan untuk senantiasa menjaga integritas baik secara individu maupun bangsa. Disini terlihat sekali bahwa indonesia itu didikte, dan kehilangan kebebasan dalam mengatur kebijakan ekonominya ketika berhadapan dengan IMF. Ketiga, utang luar negeri melanggar prinsip fair deadling dalam islam. Dilihat dari proses diutarakan terdahulu, tidak ada proses tawar-menawar yang adil dalam pemberian utang. Tawar menawar yang terjadi sangat bias kearah keuntungan negara maju dan kerugian bagi negara penerima. Hutang Luar Negeri Dalam Prespektifislam Secara umum terdapat dua pandangan tentang hutang luar negeri sebagai altematif menutup deficit anggaran negara. Pandangan pertama menganggap bahwa external financing merupakan hai yang diperbolehkan dalam Islam, meskipun bentuk dan mekanismenya memerlukan modifikasi. Pandangan yang kedua menganggap bahwa negara Islam tidak selayaknya mencari utang luarnegri sebagai penutup savinggapnya. (Mannan, 1992 : 237-238) 


\section{SIMPULAN}

Dalam bahasa Arab, utang (al- Dayn) merupakan sesuatu yang berada dalam tanggung jawab orang lain. Dayn juga disebut juga dengan wasfu alDzimmah(sesuatuyang harus di lunasi atau diselesaikan). Menurut Hanafiyah, dayn termasuk kepada al-Milk.Utang dapat di kategorikan pada al-Mal al-Hukmi::”Sesuatu yang dimiliki oleh pemberi utang, sementara harta itu berada pada yang berutang”. Sehingga utang negara adalah milik rakyat dan digunakan untuk keperluan rakyat. Selain itu, utang (al-Dayn)secara bahasa juga bermakna memberikan pinjaman. Al- Dayn mensyaratkan jangka waktu tertentu dalam pengembalian utang,hal ini berbeda dengan al- Qardh yang tidak mensyaratkan jangka waktu tertentudalam pengembalian utang. Utang luar negri dalam Islam di perbolehkan, selama bisa atau sanggup membayar, dan utang tidak mengandung riba. Kemudian utang di peruntukkan untuk hal yang mendesak. Namun sebaiknya utang di hindari. 


\section{DAFTAR PUSTAKA}

'Athif, Samih, Az-Zain. 1995. Al Mu'amalat. Cetak ke -1. Lebanon: Dar al Kitab alLubnani.

Arikunto, Suharsimi, 2002, Prosedur Penelitian, Jakarta: Rineka Cipta

Huda , 2012. Nurul dkk, Keuangan Publik Islam Pendekatan Teoritis dan Sejarah, kencana: Jakarta.

Mannan, Abdul (1992), Teori dan Praktek Ekonomi Islam, Yogyakarta, PT DanaBhakti Wakaf.

Sotari, Djam'an dan Aan Komariah, 2009, Metodologi Penelitian Kualitatif, Bandung: PT. Alfabeta.

\section{Skripsi:}

Bonokeling, Eka., 2016. Pengaruh Utang Luar Negri, Tenaga Kerja, dan Ekspor,terhadap produk domestik bruto di Indonesia tahun 1986-2015. Yogyakarta: UNY

Ditjen Pengelolaan Pembiayaan dan Risiko Kementerian Keuangan, Selasa (27/6/2017).

Kurniasari, Dwi., 2017. Pengaruh Utang Luar Negeri, Penanaman Modal Asing, Penanaman Modal Dalam Negri Dan Tenaga Kerja Terhadap Pertumbuhan Ekonomian Indonesia, Lampang: Universitas Lampug.

Tafonao, Niati., 2016. Menganalisis Faktor-Faktor Yang Mempengaruhi Utang Luar Negeri Indonesia, Semarang: Universitas diponegoro.

www. Baranewsaceh.co 31 oktober 2018. Pukul 16.15. wib. 